\title{
Breeding dry beans for processing
}

\author{
By M. R. Stilwell, H. F. Heinz Co. Ltd, Hayes Park, Middlesex
}

Dry beans, Phaseolus vulgaris L., are one of the major crops in Latin America and annual per capita consumption reaches 20 and $25 \mathrm{~kg}$ respectively in Mexico and Brazil (Sanders, 1980). In these countries, dry beans represent an important source of vegetable protein for low-income families, for whom they can constitute 10\% by weight of the diet (Bressani, 1972).

In North America and Europe lesser but nonetheless significant quantities are used by the food processing industry for the production of canned beans in tomato sauce. In Great Britain, where this product is particularly popular, over 80000 tons of dry beans are processed annually, to produce 'baked beans'. Originally a product of North American origin, 'baked beans' are thought to have been initially produced by the firm of Burnham and Merrill in 1875 (Potter, 1959) to supply their fishing fleet, which could account for the beans being known as Navy beans. The first official record of this product, however, dates back to 1877 when W. K. Lewis of Boston registered a patent for the process (Bitting, 1973).

These beans which are also referred to as Pea beans are currently produced in the state of Michigan in the USA, in the province of Ontario in Canada and in minor quantities in South America and Africa.

\section{Varieties, production and quality standards}

All major varieties within this class of dry beans are derived from Robust, a disease resistant selection from a local Michigan land race released in 1915 (Spragg \& Down, 1921).

Michelite, a cross between Robust and Early Prolific (Down \& Thayer, 1938) gave rise by induced mutation with X-rays (Down \& Andersen, 1956) to a precursor of Sanilac (Andersen et al. 1960) and its derivatives Seaway (Andersen et al. 1963), Gratiot (Adams \& Andersen, 1962), Seafarer (Adams et al. 1964) and more recently Tuscola (Adams \& Saettler, 1977).

The narrow germplasm base of these varieties (Adams, I 977; Bassiri \& Adams, 1978) could account for an apparent barrier to higher yields in the state of Michigan (MBSA, 1978; 1981) demonstrated by the static yield levels over the past 30 years (see Table $\mathrm{I}$ ).

An important factor which has contributed to this lack of diversity is that the processing characteristics of the various genotypes have a profound influence on the appearance and acceptability of the final product.

The introduction of new varieties is therefore subject to their meeting specific standards for physical appearance and processing performance. The physical appearance of the bean seed (the beans should be small I 8--20 $\mathrm{g} / 100$ seeds, white and oval to spherical in shape) is easily observed, highly heritable (Adams \& 
Table 1. Average yields of dry beans in the State of Michigan USA $1951-80^{*}$

$\begin{array}{cc}\text { Five year average } & \text { Yields (kg/ha) } \\ 1951-55 & 1094 \\ 1956-60 & 1197 \\ 1961-65 & 1426 \\ 1966-70 & 1293 \\ 1971-75 & 1139 \\ 1976-80 & 1341 \\ & \\ \text { Michigan Bean Shippers Association. }\end{array}$

Bedford, 1973) and consequently presents few difficulties to any bean improvement programme. Processing characteristics on the other hand can only be monitored by tests which must simulate commercial practices.

These tests involve the sacrifice of seed, which is frequently not possible in the important early generations of a breeding programme. The results produced by these evaluations are essentially the subjective comparison with a standard variety, usually the variety Sanilac.

Three aspects are considered. The appearance of the processed beans, which should remain entire and not clump together. The product should be free of any distinctive flavours, since in the standard, the major perceptible taste is that of the sauce. The texture of the beans should be firm but not 'chewy' and the testa of the bean seed virtually unnoticeable. In this respect it is of interest to note that subjective assessment correlates well with the results of objective tests utilizing a Kramer Shear Press (Hosfield \& Uebersax, I 980) (see Table 2).

An additional consequence of these restrictions on the introduction of new genotypes, has been the failure of the development of alternative areas of production. This has occurred, either because locally adapted varieties do not possess suitable processing characteristics or conversely, because the Michigan Navy bean varieties could not be successfully grown.

\section{Breeding for improved productivity and maintenance of processing characteristics}

The production of new genotypes with superior performance over a wide range of conditions is widely recognized as being desirable.

The assessment of this characteristic requires that the genotypes be tested over a range of environments, usually locations and years. The interpretation of the results produced has been assisted by the observation, that for many crops, the performance of individual genotypes is related linearly to a measure of the general fertility. This is usually provided by the over-all mean of the genotypes tested in each environment. (Yates \& Cochran, 1938; Finlay \& Wilkinson, 1963).

The linear regression coefficient characterizes the individual genotypic response to environmental change.

Those genotypes with a low regression coefficient $(b<\mathrm{I} \cdot 0)$ demonstrate a below 
Table 2. Processing characteristics of high yielding genotypes of dry bean selected from the CIAT bean germplasm collection

\begin{tabular}{|c|c|c|c|c|c|}
\hline Variety & Origin & Appearance & Flavour & Texture & $\begin{array}{c}\text { Texture } \\
\text { (kg force/roog) }\end{array}$ \\
\hline Seafarer & MSU & Standard & Standard & Standard & - \\
\hline Sanilac & MSU & Standard & Standard & Standard & $72 \cdot 2$ \\
\hline PC-6 & S. Africa & Standard & Standard & Standard & - \\
\hline Ex Rico 23 & CIAT & Standard & Standard & Tough & $88 \cdot 5$ \\
\hline NEP 2 & Costa Rica & Small & Standard & Tough & 87.8 \\
\hline Brazil 2 & Brazil & Large & Bean & Tough & $99 \cdot 2$ \\
\hline $\mathrm{S}-630$ & Brazil & Standard & Bean & Very tough & - \\
\hline Jamapa & Venezuela & Standard & Bean & Very tough & - \\
\hline PI 309804 & USDA & Standard & Bean & Very tough & - \\
\hline San Fernando & Costa Rica & Standard & Bean & Very tough & II $8 \cdot 1$ \\
\hline
\end{tabular}

-As measured using a Kramer Shear Press (Hosfield \& Uebersax, 1980).

average response and conversely those with a high regression coefficient $(b>\mathbf{I} \cdot 0)$ an above average response to improved fertility.

In addition the mean square deviation from regression provides a measure of the reliability of this response. (Erberhart \& Russell, I g66). It has been suggested that in Phaseolus vulgaris L. particular attention should be given to this concept. (Evans, 1973).

Initial steps in this direction have been made by the Centro International de Agricultura Tropical (CIAT) with trials of twenty genotypes at forty different sites. (Voysest, 1977; Laing, 1978). This study has revealed that considerable variation in level of response exists within this species.

In an attempt to extend this work a number of the more promising genotypes were chosen and used as parents, where a high mean yield, level of response to environmental fluctuations and adequate processing characteristics were the primary objectives. A high mean yield and adequate processing characteristics represent clear cut objectives. The choice of specific levels of sensitivity to changes in general fertility, however, must depend upon an assessment of the requirements of the grower.

Two levels of response could be desirable. In areas of low productivity and technology, where the security of production is at a premium, insensitivity to environmental fluctuations, characterized by a low regression coefficient, will provide insurance against crop failure. Alternatively in areas where technology can be utilized to maximize the potential of that environment, a sensitivity to change, which corresponds to a high regression coefficient, will permit an adequate response to improvements in crop husbandry.

Amongst the parental genotypes chosen and tested over twenty-seven sites, the varieties Seafarer and PC6 represent the former case, albeit with a low mean yield, and S-630 and PI 309804 represent the latter (Table 3 and Fig. I). Jamapa represents the average variety with an intermediate level of response $(b=1 \cdot 05)$. 
Table 3. Mean yields, regression coefficients and mean square deviations from regressions of selected genotypes of dry beans

$\begin{array}{lccc}\text { Variety } & \begin{array}{c}\text { Mean yield } \\ (\mathrm{kg} / \mathrm{ha})\end{array} & \begin{array}{c}\text { Regression } \\ \text { coefficient }\end{array} & \begin{array}{c}\text { Mean square } \\ \text { deviations from } \\ \text { regression }\end{array} \\ \text { Seafarer } & 1034 & 0.77 \pm 0.07 & 71595 \\ \text { PC-6 } & 1038 & 0.71 \pm 0.06 & 50864 \\ \text { Ex Rico 23 } & 1453 & 1.03 \pm 0.08 & 99778 \\ \text { NEP 2 } & 1220 & 0.93 \pm 0.09 & 136310 \\ \text { Brazil 2 } & 1397 & 0.97 \pm 0.09 & 137020 \\ \text { S-630 } & 1704 & 1.23 \pm 0.06 & 66794 \\ \text { Jamapa } & 1627 & 1.05 \pm 0.07 & 68677 \\ \text { PI 309804 } & 1760 & 1 \cdot 22 \pm 0.07 & 77654 \\ \text { San Fernando } & 155^{2} & 1 \cdot 09 \pm 0.08 & 93460 \\ \text { L.SD 0.05 } & 249 & & \end{array}$

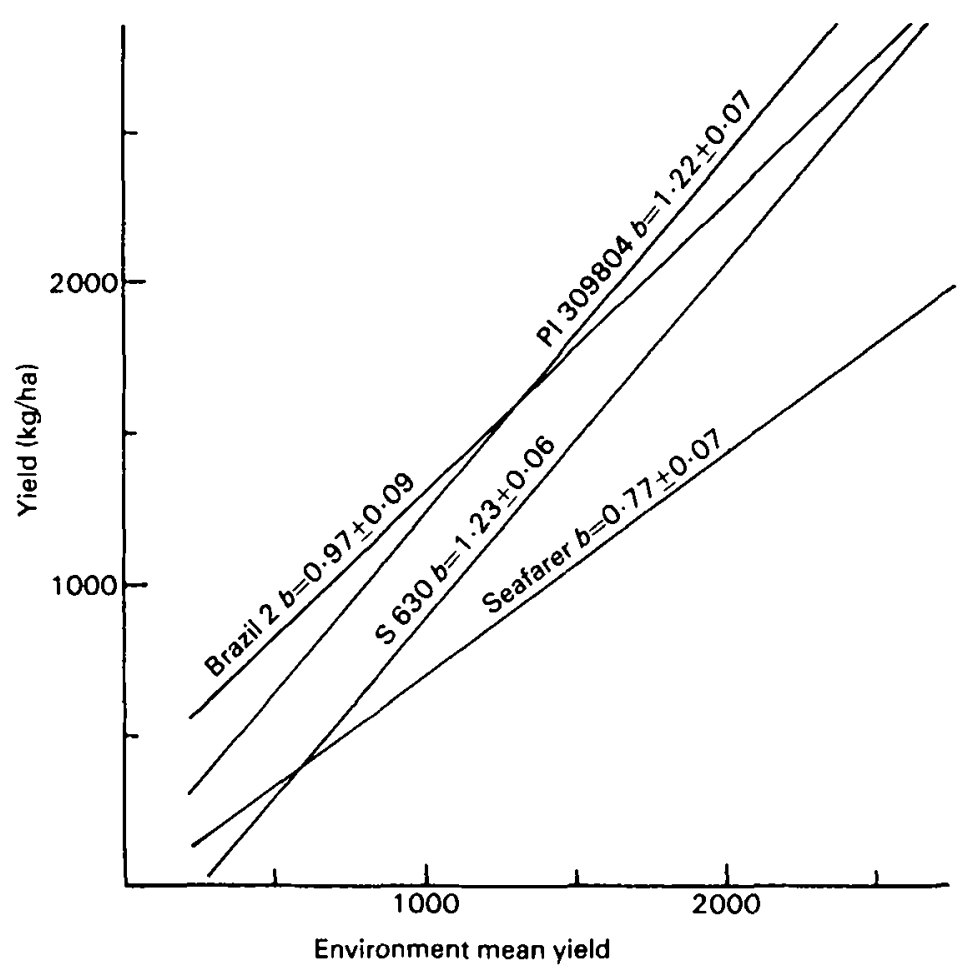

Fig. 1. Yield (kg/ha) of selected genotypes of dry beans in different environments. Nine genotypes tested over twenty-seven environments.

The low mean yield and low regression coefficient obtained for the variety Seafarer, which is similar to that obtained for the variety Sanilac by CIAT (Laing, 1978), is a possible additional explanation of the limited yield levels in Michigan. 
The processing characteristics of these genotypes have been examined (Table 2). It is of interest to note that the genotypes with coloured seeds have a distinct bean flavour which the white seeded genotypes do not. Since the genotypes NEP 2 and San Fernando are isogenic for P, the pigmentation factor (Moh, 197I), it is likely that this flavour and indeed some textural differences, possibly due to a lower moisture uptake, are associated with the pigmentation of the seed coat.

The progeny of crosses is selected for desirable seed characters, and various aspects of plant architecture, appearance and disease resistance. In the $F_{3}$ or $F_{4}$ generation processing tests permit the elimination of undesirable genotypes (Table 4).

Testing over varied environments in the early generations will also, it is hoped, provide a means of selection for yield and response to environmental fluctuations (Table 5 and Fig. 2).

Table 4. Processing characteristics of the progeny from crosses of various dry beans

\begin{tabular}{llll}
\multicolumn{1}{c}{ Variety } & Appearance & Flavour & Texture \\
Sanilac $(\mathrm{STD})$ & Standard & Standard & Standard \\
$($ EXR $\times$ PI) & Standard & Standard & Standard \\
$($ EXR $\times$ J) & Standard & Standard & Tough \\
$($ SF $\times$ PI) & Standard & Beans & Soft \\
$(\mathrm{SF} \times \mathrm{J})$ & Standard & Standard & Standard \\
$(\mathrm{SF} \times \mathrm{EXR})$ & Standard & Standard & Very tough
\end{tabular}

Table 5. Mean yields, regression coefficients and mean square deviations from regressions of progeny from crosses of various dry beans

\begin{tabular}{|c|c|c|c|c|}
\hline Variety & Abbreviation & $\begin{array}{c}\text { Mean yield } \\
(\mathrm{kg} / \mathrm{ha})\end{array}$ & $\begin{array}{l}\text { Regression } \\
\text { coefficient }\end{array}$ & $\begin{array}{l}\text { Mean square } \\
\text { deviations from } \\
\text { regression }\end{array}$ \\
\hline PI 309804 & PI & 1718 & $1 \cdot 33 \pm 0 \cdot 16$ & 70037 \\
\hline Jamapa & J & I 593 & $1 \cdot 16 \pm 0 \cdot 13$ & $4393^{8}$ \\
\hline Ex Rico 23 & EXR & 1310 & $0.70 \pm 0.16$ & 69056 \\
\hline Seafarer & $\mathrm{SF}$ & 841 & $0.4^{8} \pm 0.11$ & 28942 \\
\hline$P I \times J$ & - & 2013 & $1.09 \pm 0.18$ & 81400 \\
\hline $\mathrm{EXR} \times \mathrm{PI}$ & - & 1986 & $1.35 \pm 0.24$ & 151772 \\
\hline $\mathrm{EXR} \times \mathrm{J}$ & - & 1864 & $0.85 \pm 0.09$ & $2435^{6}$ \\
\hline $\mathrm{SF} \times \mathrm{PI}$ & - & $195^{I}$ & $0.75 \pm 0.3^{\circ}$ & 237119 \\
\hline $\mathrm{SF} \times \mathrm{J}$ & - & 1664 & $1.07 \pm 0.19$ & 100614 \\
\hline $\mathrm{SF} \times \mathrm{EXR}$ & - & I 444 & $0.79 \pm 0.23$ & 137632 \\
\hline $\operatorname{LSD} 0.05$ & & 590 & & \\
\hline
\end{tabular}




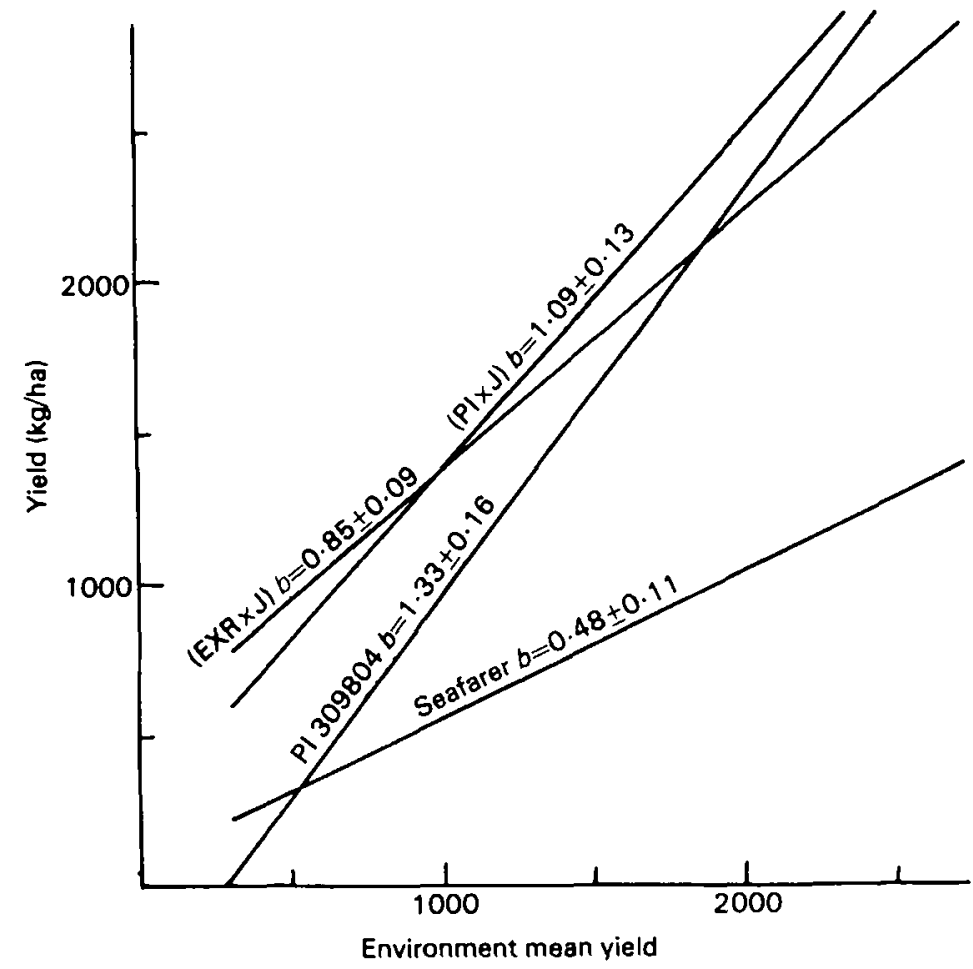

Fig. 2. Yield (kg/ha) of selected genotypes of dry beans in different environments. Thirty-seven genotypes tested over nine environments.

\section{REFERENCES}

Adams, M. W. (1977). Euphytica 26, 665 .

Adams, M. W. \& Andersen, A. L. (1962). Notice of the release of Gratiot a new variety of navy bean. Mich. Agr. Exp. Sta. and USDA, ARS Crops Research Division.

Adams, M. W., Andersen, A. L. \& Saettler, A. W. (1964). Notice of the release of Seafarer, a bush type navy bean variety. Mich. Agr. Exp. Sta. and USDA, ARS Crops Research Division.

Adams, M. W. \& Bedford, C. L. (1973). In Nutritional Improvement of Food Legumes by Breeding, Proceedings of a Symposium sponsored by PAG, Rome, July 1972 [M. Milner, editor]. p. 289.

Adams, M. W. \& Saettler, A. W. (1977). Notice of the release of Tuscola, a new mechanical damage resistant navy bean. Mich. Agr. Exp. Sta. and USDA, ARS Crops Research Division.

Andersen, A. L., Adams, M. W. \& Whitford, G. (1963). Mich. St. Univ. Agric. Exp. Stn Q. Bull. 45, 548 .

Andersen, A. L., Down, E. E. \& Whitford, G. (1960). Mich. St. Univ. Agric. Exp. Stn Q. Bull. 43, 214.

Bassiri, S. \& Adams, M. W. (1978). Euphytica 27, 707.

Bitting, A. W. (1973). In Appertixing or The Art of Canning; Its History and Development, p. 404. San Francisco, California: The Trade Pressroom.

Bressani, R. (1972). In Nutritional Improvement of Food Legumes by Breeding, Proceedings of a Symposium sponsored by PAG, Rome, July 1972, [M. Milner, editor]. p. 15 .

Down, E. E. \& Andersen, A. L. (1956). Science, N.Y. 123, 223.

Down, E. E. \& Thayer, J. W. (1938). Mich. St. Coll. Agric. Exp. Stn Spec. Bull. No. 295.

Erberhart, S. A. \& Russell, W. A. (1966). Crop Sci. 6, 36.

Evans, A. M. (1973). In Potentials of Field Beans and Other Food Legumes in Latin America, p. 279. Cali, Colombia: CIAT Information Services. 
Finlay, K. W. \& Wilkinson, G. N. (1963). Aust. F. Agric. Res. 14, 742.

Hosfield, G. L. \& Uebersax, M. A. (1980). F. Am. Soc. Hort. Sci. 105 (2), 246.

Laing, D. R. (1978). Adaptability and Stability of Performance in Common Beans, Phaseolus vulgaris L. International communication. Cali, Colombia: CIAT.

Michigan Bean Shippers Association (1978). Mich. Dry Bean Dig. 2 (3), 5.

Michigan Bean Shippers Association (1981). Mich. Dry Bean Dig. 5 (2), 32.

Moh, C. C. (1971). Euphytica 20, 119.

Potter, S. (I959). The Magic Number. The story of ' 57 ', London: Max Reinhardt.

Sanders, J. H. (1980). International Document Econ. 1 . 5. Cali, Colombia: CIAT.

Spragg, F. A. \& Down, E. E. (1921). Mich. St. Coll. Agric. Exp. Stn Spec. Bull. No. 108.

Voysest, O. (1977). Metodologia y análisis de resultados de los primeros ensayos de viveros internacionales de rendimiento y adaptación del Frijol IBYAN. International communication. Cali, Colombia: CIAT.

Yates, F. \& Cockran, W. G. (1938). J. Agric. Sci., Camb. 28, $55^{6}$. 